\title{
Banana Stem Bokashi and its Effect to Increase Soybean Yield (Glycine max L. Merrill) in Coastal Sands Area
}

\section{Khavid Faozi ${ }^{1 *}$, Prapto Yudono ${ }^{2}$, Didik Indradewa ${ }^{2}$ and Azwar Ma'as ${ }^{3}$}

${ }^{1}$ Department of Agrotechnology, Faculty of Agriculture, Jenderal Soedirman University, Purwokerto, Central Java, Indonesia

${ }^{2}$ Department of Agronomy, Faculty of Agriculture, Gadjah Mada University, Yogyakarta, Indonesia

${ }^{3}$ Department of Soil Science, Faculty of Agriculture, Universitas Gadjah Mada, Yogyakarta, Indonesia

\begin{abstract}
The development of soybeans in coastal sand area besides using adaptive cultivars also requires the input of organic matter to increase its productivity. One source of organic material that has not been widely used is banana stem. The research aimed to study: 1) the characteristics of banana stems bokashi and its role to improving the growth and yield of some soybean cultivars, and 2) Response growth and yield of soybean cultivars at the level of banana stem bokashi in the coastal sands. The research is a laboratory and field experiment conducted for 6 months from October 2016 until March 2017. Pot experiments in the field have been done in Samas coastal sands, Srigading Village, Sanden Sub-district, Bantul Regency, special Region of Yogyakarta. The factorial experiment (4 $\times 12$ ) was repeated 3 times, arranged in a complete randomized block design (RCBD). The first factor was dose banana stem bokashi including $0,20,40$, and 60 t.ha $^{-1}$; was tested on 12 soybean cultivars namely Anjasmoro, Argomulyo, Burangrang, Demas 1, Dena 1, Devon 1, Gamasugen 1, Gema, Gepak ljo, Grobogan, Kaba, and Slamet. The observational data were analyzed by the variant analysis of the error rate of $5 \%$ and if significantly different was followed by DMRT $5 \%$ error level. The results showed that bokashi made from banana stem has chemical composition which can be used as a soil conditioner and as organic fertilizer. Soybean cultivars respond to various doses of bokashi given. In general, soybean cultivars increased growth and yield of seeds in bokashi application to optimum dosage, and did not increase again with higher doses. However, there are also soy cultivars that are not responsive or even depressed growth and yield of seeds when given bokashi banana stem.
\end{abstract}

Keywords: Banana stem bokashi; Soybean cultivar; Coastal sands area; Fertilizer; Seed yield

\section{Introduction}

Indonesia is an archipelagic country that has a large and long coastal area. The landform of the coastal area is generally grouped over muddy shores, sandy shores, and rocky andeshite [1]. According to Shiddieq [2], the area of coastal sand in Indonesia reaches about 1.060.000 hectares. The area of the Special Region of Yogyakarta which stretches along \pm $110 \mathrm{~km}$ and is adjacent to the coastline is a coastal area, with an area of $\pm 8,250 \mathrm{ha}$, about 3,408 ha is a sand field stretching along $\pm 33 \mathrm{~km}$ across the southern part of Bantul and Kulon Progo districts [3].

The utilization of Samas beach sand land in Bantul Regency Special Region of Yogyakarta has been started since 1986 that is for horticulture crop cultivation [4], whose productivity is highly dependent on the input of fertilizer especially nitrogen [5]. The use of nitrogen fertilizers in sand soils has great potential to contaminate the coastal environment $[6,7]$. Therefore, it is necessary to try the development of soybean plants that have the properties to fix $\mathrm{N}_{2}$ from the atmosphere, so it does not require a lot of nitrogen fertilizer. Salvagiotti [8] suggests about 50\%$60 \%$ of the $\mathrm{N}$ requirement in soybean plants can be fulfilled by biological fixing of $\mathrm{N}_{2}$ at at various yield levels and growing environments.

One effort to increase soybean productivity in coastal sand is to provide adaptive varieties $[9,10]$. The adaptability of a variety can be measured by its maximum production ability in a new growing environment. The growing environment of specific coastal sand land will need to try the use of superior cultivars available with various characters to know the power of adaptation.

Coastal sand has sufficient groundwater resources, and is not affected by floods and can be utilized throughout the year for crop cultivation [11]. However, coastal sand land has the main constraints of low nutrient availability both macro and micro nutrients $[12,13]$ as well as low nutrient storage ability [14]. In order to support the success of soybean cultivation in coastal sand, besides using adaptive soybean cultivar (genotype), it also requires production input in the form of organic matter. One source of organic material is abundant and has not been widely used is banana stem.

Banana production center in Bantul Regency is located in three districts of Bambanglipuro, Kretek, and Pandak with total production reaching 10.8 thousands tons every year [15]. The development is by utilizing the yard for planting banana trees. Banana tree is also commonly found around the southern coastal area of Bantul regency, so banana plant waste, especially its stem can be used as a source of organic materials to support agriculture in coastal sand.

Based on the material content of mineral and organic material, banana stem is potential to be utilized among others as raw material of bokashi/ compost [16-20]. Banana stem is a potential material of

*Corresponding author: Faozi K, Department of Agrotechnology, Faculty of Agriculture, Jenderal Soedirman University, Purwokerto, Central Java, Indonesia, Tel: +6281327029354; E-mail: khavidfaozi@yahoo.com

Received November 12, 2018; Accepted December 06, 2018; Published December 28, 2018

Citation: Faozi K, Yudono P, Indradewa D, Ma'as A (2018) Banana Stem Bokash and its Effect to Increase Soybean Yield (Glycine max L. Merrill) in Coastal Sands Area. Agrotechnology 7:184. doi: 10.4172/2168-9881.1000184

Copyright: (c) 2018 Faozi K, et al. This is an open-access article distributed unde the terms of the Creative Commons Attribution License, which permits unrestricted use, distribution, and reproduction in any medium, provided the original author and source are credited. 
bokashi (compost), because it contains C (21.85\%), N (0.28\%), P (0.98\%), K (3.30\%) and C/N (78) [21]. Through composting using EM4 for 3 weeks bokhasi will be obtained with NPK nutrient content composition $\left(0.94 \% \mathrm{~N}, 1.45 \% \mathrm{P}_{2} \mathrm{O}_{5}\right.$ and $\left.1.81 \% \mathrm{~K}_{2} \mathrm{O}\right)$ and $\mathrm{C} / \mathrm{N}$ ratio $(21)$. According to Kusumawati [22] bokashi made from 2 month old banana stem containing $\mathrm{C}$ organic (29,7\%), $\mathrm{C} / \mathrm{N}$ ratio (17,8\%), $\mathrm{pH} \mathrm{H}_{2} \mathrm{O}(5,64)$, total NPK $(7,74 \%)$ is qualified as organic fertilizer.

The research aimed to study: 1) the characteristics of banana stems bokashi and its role to improving the growth and yield of some soybean cultivars, and 2) Response growth and yield of soybean cultivars at the level of banana stem bokashi in the beach sand.

\section{Materials and Methods}

\section{Making banana stem bokashi}

Materials and tools for making bokashi consists of banana stem, charcoal husk, rice bran, dolomite, EM4, molasses, water, plastic drum, tarpaulin, shovel, bucket, sprayer, ground thermometer, EC meter, as well as materials and tools analysis of bokashi chemical properties. The composition of bokashi material based on dry weight (oven) includes: banana stem (60\%), charcoal husk (20\%), cow manure (10\%), rice bran (6\%), and dolomite (4\%). Effective microorganisms are prepared by mixing EM4 solution with molasses and water ratio of 1 liter EM4, 1 liter of molasses, and 50 liters of water. The solution is made minimum 2 days (48 hours), before used for fermentation of organic material [23].

The bokashi material is mixed evenly using a shovel, then sprayed EM solution using a sprayer while the mixture of the ingredients is stirred. Bokashi fermentation is done by incubating the material on a container the size of $100 \mathrm{~cm} \times 80 \mathrm{~cm}$, with a thickness of $60 \mathrm{~cm}$, with a closed sack. Temperature was observed daily in the first week, and when it rose to $50^{\circ} \mathrm{C}$, the inversion was performed by stirring while sprayed again with EM solution, and left open for several hours, then the material was re-incubated with a sack (Figure 1).

Observation of the next temperature is done every 2 days once up to 30 days of fermentation. The chemical composition of banana stem bokashi was observed at 0,14 , and 28 days after fermentation to determine the $\mathrm{C} / \mathrm{N}$ ratio change and its potential nutrient content at the decomposition rate of the material. Readymade bokashi is characterized by a physical change of material that already resembles the soil (blackish color), with the temperature already stabilized to follow the room temperature.

The role of bokashi in improving the growth and yield of soybeans

The research was conducted at Samas beach sand, Srigading village, Sanden district, Bantul district, Yogyakarta Special Region. Research time for 4 months, from January to April 2017. The experiment was a pot experiment in the field, with factorial treatment $(4 \times 12)$ prepared with Completely Randomized Block Design (RCBD). The first factor is the dosage of bokashi (B) i.e without bokashi (B0) and bokashi banana dose 20 t.ha $^{-1}$ (B1), 40 t.ha-1 (B2), and 60 t.ha ${ }^{-1}$ (B3); and the second factor is the soybean cultivar (V) i.e Anjasmoro 1 (V1), Argomulyo 2 (V2), Burangrang (V3), Demas 1 (V4) Dena 1 (V5), Devon 1 (V6), Gamasugen 1 (V7) Echoes (V8), Gepak Ijo (V9), Grobogan (V10), Kaba (V11), and Slamet (V12). The experimental unit consists of 6 pots each containing 2 plants each pot, with 3 replications so that there are a total of 864 pots.

The sand is sieved using a $2 \mathrm{~mm}$ sieve to separate the litter and dirt. Sand media weighed as much as $15 \mathrm{~kg}$, and included polybags.
Treatment of bokashi dosages of $0,20,40$, and 60 t.ha $^{-1}(0,90,180$, and 240 g.pot $^{-1}$ ) was administered by mixing on the sand medium evenly in polybags. The media were watered and maintained at field capacity conditions for 2 days before soybean seeds were planted. Seeds were inoculated with $5 \mathrm{~g}^{\mathrm{kg}} \mathrm{kg}^{-1}$ legin (Rhizobium sp.) and planted with a depth of 2-4 cm, as many as $2-4$ seeds per planting hole. At the age of 1 week after planting, leaving 2 plants as a sample plant, by cutting plants that grow poorly. The soil moisture is maintained under field capacity conditions, adding water according to water loss through evapotranspiration. NPK fertilized plants (16-16-16), doses of 100 kg.ha ${ }^{-1}$, were sprayed on plants at ages 2 and 4 weeks after planting. Pest control is adjusted to the condition of cropping, pest control using insecticides while controlling the disease using fungicide. Weeds are grown manually controlled, periodically revoked so that weed-free crops during its growth.

The observations of growth components include leaf area, shoot dry weight, root dry weight, and root/shoot ratio. Harvesting is done when $95 \%$ of the soybean pod is fully ripe (R8), marked pods are brown and plant leaves have fallen out. Observation of crop yield is the weight of soybean seeds. The observational data were analyzed by variant analysis according to factorial design, when it was significantly different with DMRT at $5 \%$ error level to know the response of soybean cultivar on banana stem bokashi treatment.

\section{Results and Discussion}

\section{Characteristic banana stem bokashi}

Banana stem bokashi shows have been decomposed and ready for use at 4 weeks after fermentation. The change in the temperature and electrical conductivity during decomposition are shown in Figures 2 and 3, with the chemical composition of bokashi as shown in Table 1.

Bokashi temperature increased rapidly during the first 5 days of fermentation from $26.96^{\circ} \mathrm{C}$ to $55.06^{\circ} \mathrm{C}$ (Figure 2). The bokashi temperature is too high $\left(>50^{\circ} \mathrm{C}\right)$, it needs to be decreased by stirring the bokashi mixture, and sprayed again with EM solution, and left open for about 2 hours. The temperature of bokashi gradually decreases from the sixth day until the third week of fermentation to about $30^{\circ} \mathrm{C}$, and down again near room temperature at the end of the fourth week of fermentation time.

Electrical conductivity (EC) of bokashi material solution increases to a certain time limit along with the length of fermentation time. The

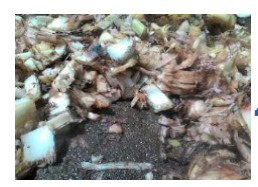

1

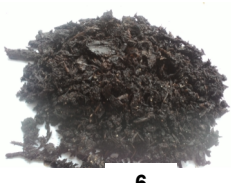

6
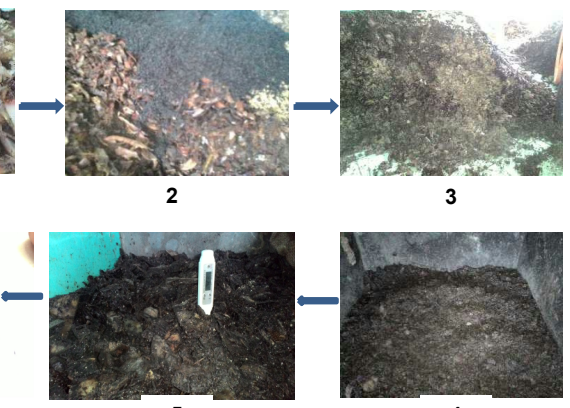

5

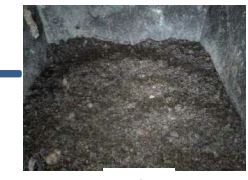

Descriptions : 1 . The banana stem has been chopped; 2 . Mixing bokashi ingredients and spraying EM solutions; 3 . Stirring and transferring bokashi to a fermentation plot; 4. Bokashi on a fermented plot; 5. Bokashi temperature measurement; and 6 . Banana stem bokashi ( 6 weeks of fermentation) was ready for use.

Figure 1: Stages of making bokashi made from banana stems. 
Citation: Faozi K, Yudono P, Indradewa D, Ma'as A (2018) Banana Stem Bokashi and its Effect to Increase Soybean Yield (Glycine max L. Merrill) in Coastal Sands Area. Agrotechnology 7:184. doi: 10.4172/2168-9881.1000184

Page 3 of 7

\begin{tabular}{|c|c|c|c|c|c|}
\hline \multirow[t]{2}{*}{ Parameter } & \multirow[t]{2}{*}{ Unit } & \multicolumn{3}{|c|}{ Fermentation time } & \multirow[t]{2}{*}{ Methods } \\
\hline & & 0 & 14 & 28 & \\
\hline C organic & $\%$ & 32.94 & 19.62 & 18.29 & Walkey and Black \\
\hline $\mathrm{N}$ total & $\%$ & 0.65 & 1.11 & 1.16 & Kjeldahl \\
\hline $\mathrm{C} / \mathrm{N}$ ratio & & 51.07 & 17.63 & 15.72 & Calculation \\
\hline Organic Matter & $\%$ & 56.79 & 33.83 & 31.53 & Convertion \\
\hline Water content & $\%$ & 84.90 & 81.03 & 76.22 & Gravimetry \\
\hline $\mathrm{pH} \mathrm{H} \mathrm{H}_{2} \mathrm{O}$ & & 9.05 & 9.34 & 9.35 & Electrometry \\
\hline $\mathrm{P}_{2} \mathrm{O}_{5}$ total & $\%$ & 0.99 & 1.68 & 1.69 & Colorimetry \\
\hline $\mathrm{K}_{2} \mathrm{O}$ total & $\%$ & 3.18 & 2.18 & 2.00 & Flamefotometry \\
\hline Ca total & $\%$ & 2.17 & 5.39 & 5.77 & SSA \\
\hline Mg total & $\%$ & 0.26 & 0.22 & 0.22 & SSA \\
\hline \multicolumn{6}{|c|}{$\begin{array}{c}\text { Description: The sample of bokashi was analyzed at Soil Laboratory and Land Resources, Faculty of Agriculture Jenderal Soedirman, Purwokerto, Central } \\
\text { Java, Indonesia. }\end{array}$} \\
\hline
\end{tabular}

Table 1: Chemical composition of banana stem bokashi during fermentation with EM technology.

increase in EC indicates the organic matter decomposes, thus changing the compound from the complex to the simplest form, and releasing the ions. Electrical conductivity (EC) of bokashi material solution increased quadratically $\left(\mathrm{R}^{2}=0.989\right)$ following the equation of line $\mathrm{Y}=$ $-0.0005 x^{2}+0.0391 x+0,6699$ (Figure 3). The EC value of the bokashi mixture initially amounted to $0.68 \mathrm{mS} . \mathrm{cm}-1$, and gradually increased to $1.03 \mathrm{mS} . \mathrm{cm}^{-1}$ at 10 fermentation days, and continued to increase until

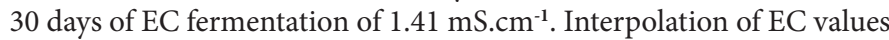
reached maximum based on the quadratic curve of $1.43 \mathrm{mS}_{\mathrm{cm}} \mathrm{cm}^{-1}$ at 39.1 days fermentation time. Bokashi fermentation at a longer time based on the equation, then the EC will decrease due to dissolved many ions that leached.

The organic carbon of bokashi material is $32.94 \%$ with low total $\mathrm{N}$ content $(0.645 \%)$, so the $\mathrm{C} / \mathrm{N}$ ratio of bokashi ingredients is still high (51.07). Along with decomposition of organic materials using EM solution, organic $\mathrm{C}$ decrease followed by total $\mathrm{N}$ increase, so $\mathrm{C} / \mathrm{N}$ ratio decreased. Bokashi is actually ready for use during fermentation for 14 days, because the $\mathrm{C} / \mathrm{N}$ ratio has dropped to 17.63. However, with high bokashi temperatures (Figure 2), it shows rapid decomposition of bokashi materials by the activity of decomposing microorganisms.

The content of organic matter also gradually decreased during the fermentation time i.e from $56.79 \%$ on day- 0 to $31.53 \%$ on the $28^{\text {th }}$ days. Bokashi water content also gradually decreased from $84.90 \%$ to $76.22 \%$. Total $\mathrm{P}_{2} \mathrm{O}_{5}$ content and total $\mathrm{Ca}$ increases, otherwise total $\mathrm{K}_{2} \mathrm{O}$ of the material actually decreases after fermentation. The total $\mathrm{Mg}$ content of the mixture of bokashi materials and after becoming bokashi relatively unchanged. The relatively high organic material indicates that bokhasi will still be gradually decomposed during use in the field. Bokashi is expected to be as conditioner of sand beach, especially in increasing the ability of sand soil to store water and plant nutrients. According to [24], the addition of compost in the sand soil significantly reduces the bulk density of the soil to $1.03 \mathrm{Mg} \cdot \mathrm{m}^{-3}$ and the soil moisture is longer. In addition, the chemical composition of bokashi containing macro nutrients $\mathrm{N}, \mathrm{P}, \mathrm{K}, \mathrm{Ca}$, and $\mathrm{Mg}$ can also function as organic fertilizer to increase the growth and yield of soybean crops.

\section{Response of soybean cultivars to level of banana stem bokashi}

Based on preliminary soil analyzes at the study sites, the soil used for pot experiments was sand beach soil containing sand fractions

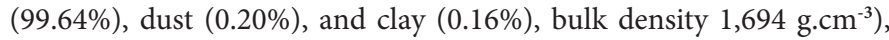
C-organic (0.091\%), N-total (0.010\%), $\mathrm{C} / \mathrm{N}$ ratio (9.10), $\mathrm{pH} \mathrm{H}_{2} \mathrm{O}$ (5.48) , EC $(25.1 \mu S)$, P-total (0.139\%), and K-total (0.005\%).

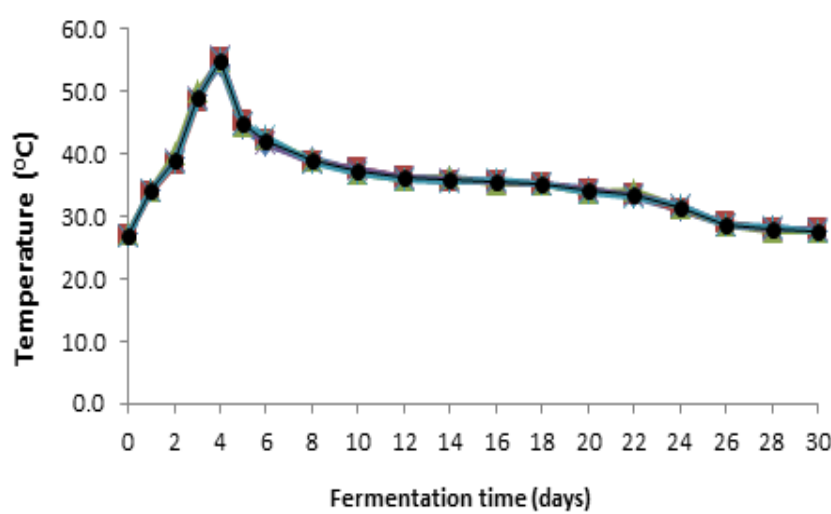

Figure 2: Changes of temperature during bokashi fermentation.

\begin{tabular}{|c|c|c|c|c|}
\hline Observation variable & Bokashi & Cultivars & Interaction & C.V. (\%) \\
\hline $\begin{array}{l}\text { Total leaf area }\left(\mathrm{dm}^{2}\right. \\
\left.\text { pot }^{-1}\right)\end{array}$ & ** & ** & ** & 8.53 \\
\hline $\begin{array}{c}\text { Shoot dry weight } \\
\left(\text { g.pot }{ }^{-1}\right)\end{array}$ & ** & ** & ** & 10.63 \\
\hline $\begin{array}{l}\text { Root dry weight } \\
\left(\text { g.pot }{ }^{-1}\right)\end{array}$ & ** & ** & ** & 11.94 \\
\hline Root/Shoot Ratio & ** & ** & $* *$ & 8.99 \\
\hline Seed weight $\left(\right.$ g.pot $\left.^{-1}\right)$ & ** & ** & ** & 18.85 \\
\hline
\end{tabular}

Description: ** significantly different by analysis of variants error level $1 \%$.

Table 2: The effect of banana stem bokashi dosage on the growth and yield of soybeans on coastal sandy land.

The application of banana stem bokashi affected the growth and yield of some soybean cultivars, which significantly showed the interaction of treatment factor in all observed variables (Table 2). Observation data of variable leaf area, root dry weight, shoot dry weight, and root/shoot ratio are presented in Tables 3-6. The seed yield variable data are presented in Figure 4.

Leaves are plant organs that work for photosynthesis [25]. The plant leaf area of some soybean cultivars is affected by the dose of bokashi given with the response depending on the cultivars. Grobogan cultivars were most responsive to bokashi from banana stem the increased leaf area from $14.02 \mathrm{dm}^{2}$.pot ${ }^{-1}$ to 24,$76 ; 26,74$; and $27.30 \mathrm{dm}^{2}$.pot ${ }^{-1}$ respectively at dose 20; 40; and 60 t.ha $^{-1}$. In general, soybean cultivars will increase the total leaf area by giving bokashi up to a dose of 60 t.ha ${ }^{-1}$ except Dena 1, Gamasugen 1, and Kaba which has decreased in the dosage. Soybean cultivars that have a total average leaf area is high, among others Anjasmoro, Argomulyo, Demas 1, and Grobogan 
Citation: Faozi K, Yudono P, Indradewa D, Ma'as A (2018) Banana Stem Bokashi and its Effect to Increase Soybean Yield (Glycine max L. Merrill) in Coastal Sands Area. Agrotechnology 7:184. doi: 10.4172/2168-9881.1000184

Page 4 of 7

\begin{tabular}{|c|c|c|c|c|c|}
\hline \multirow[b]{2}{*}{ Soybean cultivars } & & \multicolumn{3}{|c|}{ Total leaf area $\left(\mathrm{dm}^{2} \cdot\right.$ pot $\left.^{-1}\right)$} & \multirow[b]{3}{*}{ Average } \\
\hline & & & Bokashi dose (t.ha $\left.{ }^{-1}\right)$ & & \\
\hline & 0 & 20 & 40 & 60 & \\
\hline Anjasmoro & $15.78 \mathrm{~h}-\mathrm{n}$ & 20.97 c-e & $20.58 d-f$ & $14.91 \mathrm{k}-\mathrm{o}$ & 18.06 \\
\hline Argomulyo & $17.95 \mathrm{f}-\mathrm{j}$ & $21.78 \mathrm{~cd}$ & $22.03 \mathrm{~cd}$ & 26.68 a & 22.11 \\
\hline Burangrang & $10.62 \mathrm{qr}$ & $16.79 \mathrm{~g}-\mathrm{I}$ & $17.22 \mathrm{~g}-\mathrm{k}$ & 18.59 e-h & 15.80 \\
\hline Demas 1 & 14.79 k-p & 20.8 c-e & $22.02 \mathrm{~cd}$ & $23.52 \mathrm{bc}$ & 20.30 \\
\hline Dena 1 & $10.69 \mathrm{qr}$ & $17.36 \mathrm{~g}-\mathrm{k}$ & $16.48 \mathrm{~h}-\mathrm{I}$ & $15.81 \mathrm{~h}-\mathrm{n}$ & 15.08 \\
\hline Devon 1 & $13.13 n-q$ & 12.56 o-r & $18.34 \mathrm{e}-\mathrm{i}$ & $21.34 \mathrm{~cd}$ & 16.34 \\
\hline Gamasugen 1 & $9.78 \mathrm{r}$ & $15.51 \mathrm{i}-\mathrm{n}$ & 14.73 k-p & $15.11 \mathrm{j}-\mathrm{o}$ & 13.78 \\
\hline Gema & $12.05 p-r$ & 16.47 h-I & 16.54 h-I & $18.13 \mathrm{f}-\mathrm{i}$ & 15.80 \\
\hline Gepak ljo & $13.43 \mathrm{~m}-\mathrm{p}$ & 16.49 h-I & $16.61 \mathrm{~g}-\mathrm{I}$ & $19.44 \mathrm{~d}-\mathrm{g}$ & 16.49 \\
\hline Grobogan & $14.02 \mathrm{I}-\mathrm{p}$ & $24.76 \mathrm{ab}$ & $26.74 \mathrm{a}$ & $27.30 \mathrm{a}$ & 23.04 \\
\hline Kaba & $14.09 \mathrm{I}-\mathrm{p}$ & $16.39 \mathrm{~h}-\mathrm{I}$ & $17.28 \mathrm{~g}-\mathrm{k}$ & $16.59 \mathrm{~g}-1$ & 16.09 \\
\hline Slamet & 12.27 o-r & $13.97 I-p$ & 16.2 h-m & $14.90 \mathrm{k}-\mathrm{o}$ & 14.35 \\
\hline Average & 13.22 & 17.83 & 18.68 & 19.36 & $17.27(+)$ \\
\hline $\mathrm{F}$ calcutated $=5.83^{* *}$ & & & & & \\
\hline
\end{tabular}

Description: The numbers followed by the same letter show no significant difference in DMRT error level $5 \%$; **=Significantly different by analysis of variants error level $1 \% ;(+) /(-)=$ interaction of treatment factors were significant or not.

Table 3: Total leaf area several cultivars of soybean on the level of banana stem bokashi.

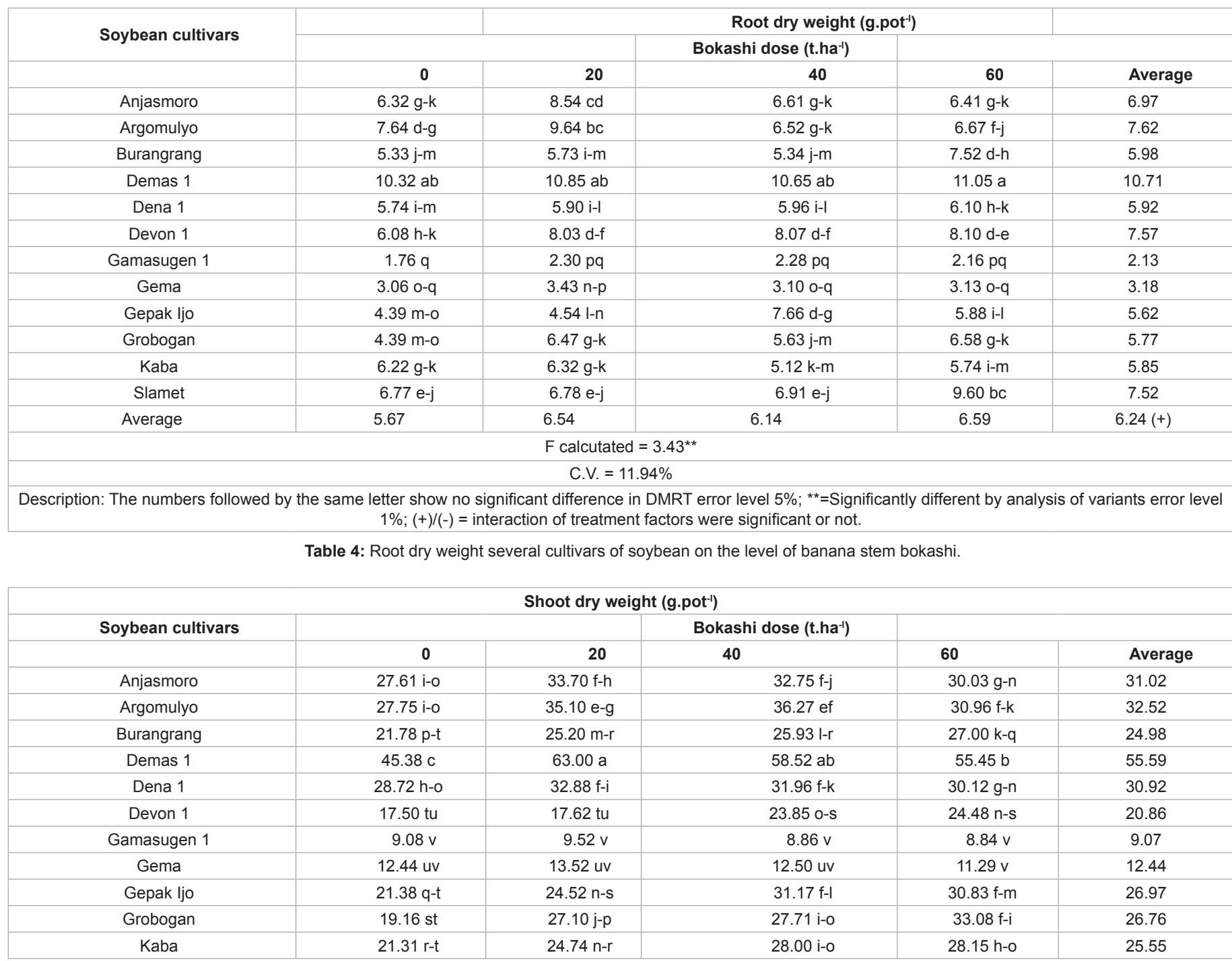


Citation: Faozi K, Yudono P, Indradewa D, Ma'as A (2018) Banana Stem Bokashi and its Effect to Increase Soybean Yield (Glycine max L. Merrill) in Coastal Sands Area. Agrotechnology 7:184. doi: 10.4172/2168-9881.1000184

Page 5 of 7

\begin{tabular}{|c|c|c|c|c|c|}
\hline Slamet & 23.51 o-s & $24.94 n-r$ & $43.55 \mathrm{~cd}$ & $39.23 \mathrm{de}$ & 32.81 \\
\hline Average & 22.97 & 27.65 & 29.99 & 29.22 & $27.46(+)$ \\
\hline \multicolumn{6}{|c|}{$\mathrm{F}$ calcutated $=4.88^{\star *}$} \\
\hline & & C.V. $=$ & & & \\
\hline
\end{tabular}

Description: The numbers followed by the same letter show no significant difference in DMRT error level $5 \%$; ${ }^{* *}=$ Significantly different by analysis of variants error level $1 \% ;(+) /(-)=$ interaction of treatment factors were significant or not.

Table 5: Shoot dry weight several cultivars of soybean on the level of banana stem bokashi.

\begin{tabular}{|c|c|c|c|c|c|}
\hline \multirow{3}{*}{ Soybean cultivars } & & \multirow[b]{3}{*}{20} & \multirow{2}{*}{$\begin{array}{c}\text { Root/Shoot ratio } \\
\text { Bokashi dose (t.ha- })\end{array}$} & \multirow[b]{3}{*}{60} & \multirow[b]{3}{*}{ Average } \\
\hline & \multirow[b]{2}{*}{0} & & & & \\
\hline & & & 40 & & \\
\hline Anjasmoro & $0.186 \mathrm{~g}-\mathrm{o}$ & $0.202 \mathrm{e}-\mathrm{j}$ & $0.168 \mathrm{j}-\mathrm{q}$ & 0.176 h-p & 0.184 \\
\hline Argomulyo & $0.216 \mathrm{e}-\mathrm{g}$ & $0.215 \mathrm{e}-\mathrm{g}$ & 0.152 o-q & 0.177 h-p & 0.190 \\
\hline Burangrang & 0.197 e-m & $0.185 \mathrm{~g}-0$ & $0.170 \mathrm{i}-\mathrm{q}$ & $0.221 \mathrm{~d}-\mathrm{f}$ & 0.193 \\
\hline Demas 1 & $0.185 \mathrm{~g}-\mathrm{o}$ & $0.147 \mathrm{pq}$ & $0.154 \mathrm{nq}$ & $0.166 \mathrm{k}-\mathrm{q}$ & 0.163 \\
\hline Dena 1 & $0.166 \mathrm{k}-\mathrm{q}$ & $0.153 n-q$ & $0.156 n-q$ & $0.171 \mathrm{~h}-\mathrm{q}$ & 0.162 \\
\hline Devon 1 & $0.258 b$ & $0.316 \mathrm{a}$ & $0.253 \mathrm{c}$ & $0.249 \mathrm{~b}-\mathrm{d}$ & 0.269 \\
\hline Gamasugen 1 & $0.163 \mathrm{l}-\mathrm{q}$ & 0.195 e-m & $0.205 e-h$ & 0.196 e-m & 0.190 \\
\hline Gema & 0.198 e-k & $0.202 \mathrm{e}-\mathrm{j}$ & $0.215 \mathrm{e}-\mathrm{g}$ & 0.195 e-m & 0.202 \\
\hline Gepak ljo & $0.171 \mathrm{~h}-\mathrm{q}$ & $0.156 n-q$ & 0.196 e-m & $0.162 \mathrm{~m}-\mathrm{q}$ & 0.171 \\
\hline Grobogan & $0.187 \mathrm{f}-\mathrm{m}$ & 0.194 e-m & $0.170 \mathrm{i}-\mathrm{q}$ & $0.166 \mathrm{k}-\mathrm{q}$ & 0.179 \\
\hline Kaba & $0.226 \mathrm{c}-\mathrm{e}$ & $0.203 \mathrm{e}-\mathrm{i}$ & $0.155 n-q$ & $0.169 \mathrm{i}-\mathrm{q}$ & 0.188 \\
\hline Slamet & $0.223 c-e$ & $0.213 \mathrm{e}-\mathrm{g}$ & $0.137 \mathrm{q}$ & 0.197 e-m & 0.193 \\
\hline Average & 0.198 & 0.198 & 0.178 & 0.187 & $0.190(+)$ \\
\hline \multicolumn{4}{|c|}{$\mathrm{F}$ calcutated $=4.84^{* *}$} & & \\
\hline \multicolumn{4}{|c|}{ C.V. $=8.99 \%$} & & \\
\hline
\end{tabular}

Description: The numbers followed by the same letter show no significant difference in DMRT error level $5 \%$; ${ }^{* *}=$ Significantly different by analysis of variants error level $1 \% ;(+) /(-)=$ interaction of treatment factors were significant or not.

Table 6: Root/Shoot ratio several cultivars of soybean on the level of banana stem bokashi.

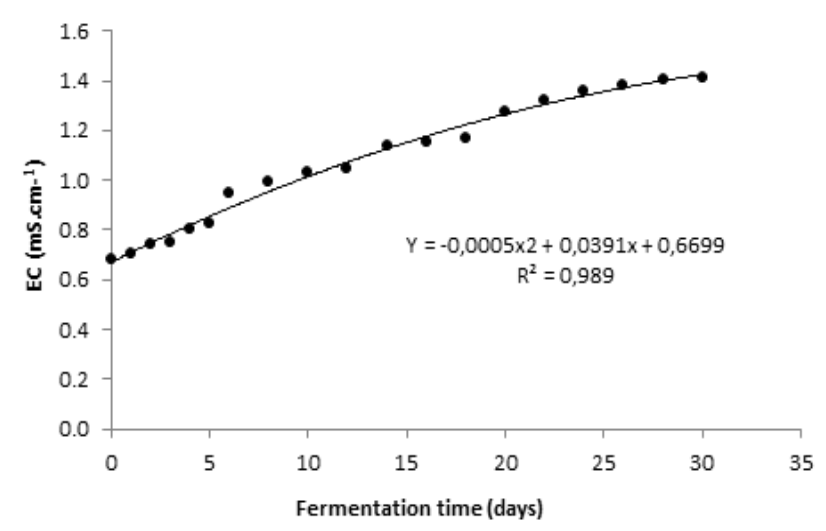

Figure 3: Changes of electrical conductivity (EC) during bokashi fermentation.

is equal to $18.06 ; 22.11 ; 20.30$; and $23.21 \mathrm{dm}^{2}$.pot ${ }^{-1}$. The cultivars that have the lowest total leaf area of Gamasugen 1 is $13.78 \mathrm{dm}^{2}$.pot ${ }^{-1}$ (Table 3 ). Soybean cultivars that have broad leaves will increase the capacity of photosynthesis [26], provided that the leaf can receive direct light [27]. Soybean cultivars in high doses of bokashi may have broad leaves, but because of the leaf arrangement that shade each other then the resulting dry matter actually decreases. Photosynthesis of plants will produce organic molecules that will eventually form the biomass of plants including among the organs of the leaves themselves, stems, pods, and plant roots.

Root of soybean crop Demas 1 cultivar showed the largest, with dry weight average reaching 10.71 g.pot $^{-1}$. Application of bokashi to 40 t.ha $^{-1}$ did not increase the root dry weight, and only on the dosage of

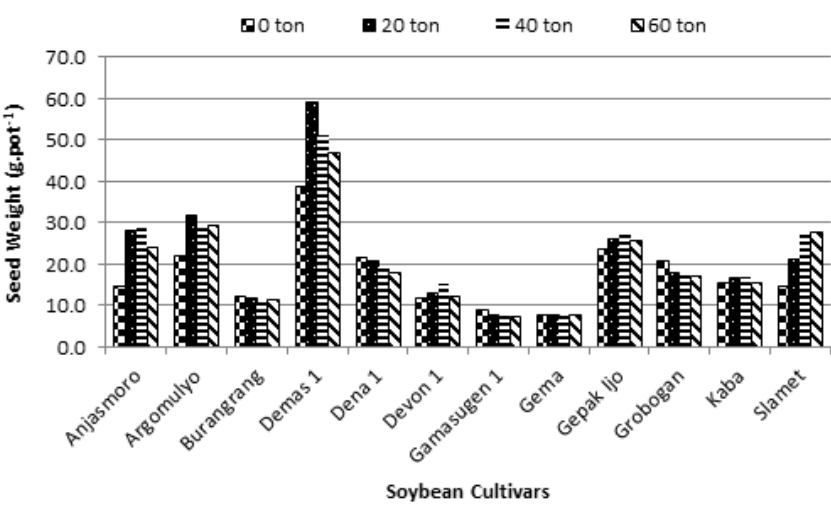

Figure 4. Seed weight several cultivars of soybean on the level of banana stem bokashi.

bokashi 60 t.ha $^{-1}$ showed the highest root dry weight of 11.05 g.pot ${ }^{-1}$. Other soybean cultivars that have high root dry weight after Demas 1 are Anjasmoro, Agromulyo, Devon 1 and Slamet respectively root weights of $6.97 ; 7.62 ; 7,57$; and 7.52 g.pot $^{-1}$. Application banana stem bokashi dose 20 and 40 t.ha $^{-1}$ effectively increased root dry weight in most cultivars used except Demas 1 and Slamet just increased root dry weight at bokashi 60 t.ha ${ }^{-1}$ dose.

The highest shoot dry weight was also on Demas 1 cultivar given banana stem bokashi dose 20 and 40 t.ha $^{-1}$ which is equal to 63.00 and 58.52 g.pot $^{-1}$, and lowest on Gamasugen 1. Application banana stem bokashi starting doses of 20 t.ha- 1 can increase the dry weight of the 
canopy on Anjasmoro Cultivars, Argomulyo, Burangrang, Demas 1, Dena 1, Gepak Ijo, Grobogan, Kaba and Slamet. The Devon 1 cultivar has begun to increase its canopy dry weight in bokashi doses of 40 to 60 t.ha-1. While shoot dry weight of Gamasugen 1 and Gema showed the smallest and relatively unchanged both on condition without bokashi and with banana stem bokashi (not responsive).

The soybean cultivar response to banana stem bokashi is mostly by reducing the root/shoot ratio, which means the resulting dry matter will be allocated more to form stem, leaf, and pod organ. However, there are also cultivars that actually multiply the roots (Gamasugen 1, Gema, Gepak Ijo, and Grobogan) although on the media the sand soil has been given with banana stem bokashi, so the root/shoot ratio the is larging.

The environment grows on beach sand with soil conditions that are not able to withstand a lot of water, the intensity of the sun and high air temperature will increase the water loss through the high leaves. The addition of organic material in the form of banana stem bokashi was responded to vary by several cultivars of soybean based on the growth of roots and shoots. Demas 1 cultivars capable of producing high dry matter (root and shoot), will multiply the allocation of dry matter to form the roots in the treatment without bokhasi and on the sand soil media given banana stem bokashi the growth of the shoot section is greater thereby decreasing the value of the root/shoot ratio.

The use of bokashi at doses of 60 t.ha-1 in coastal sand soil actually causes competition in the use of nitrogen by plants and organisms, including competition in the use of oxygen for plant roots and organisms. Therefore, most soybean cultivars growth and yields actually decrease at high bokashi doses. According to Nakhro and Dkhar [28] the application of organic fertilizers increased the organic carbon content of the soil and thereby increasing the microbial counts and microbial biomass carbon.

Decomposition of organic matter derived from the bokashi banana stem still takes place in the coastal sand soil media for up to 8 weeks after application. Decomposition of organic matter causes reduced C-organic, and increases $\mathrm{N}$-total soil so that it will reduce $\mathrm{C} / \mathrm{N}$ ratio. However, the $\mathrm{N}$ elements in the sand media released through decomposition are easily leached, causing $\mathrm{C} / \mathrm{N}$ ratios to increase with more bokashi being given over the time of incubation in the soil [29].

Demas 1 cultivars capable of producing high plant dry matter (roots and shoots), will multiply the allocation of dry matter to form roots in no bokhasi treatment; and otherwise on the sand soil media given banana stem bokashi growth of the larger shoot section. Banana stem bokashi given on the sand beach will increase the content of soil organic matter, so as to improve the ability of soil to store water and nutrients. The growth of leaf area, root part and shoot has reached maximum at optimum bokashi dosage according to cultivars, and no increase or decrease at higher bokashi dosage. Based on this it can be argued that the tested soybean cultivars are either responsive or unresponsive to bokashi; and there are adaptive or not adaptive based on the ability to produce dry weight of plants. Soybean plants including C3 plants which in conditions of temperature and intensity of high sunlight then respiration also increased [30]. High dry weight on soybean cultivars that respond to bokhasi and adaptive in coastal sand land may be due to smaller photorespiration.

Soybean cultivars capable of producing dry weight of large plants can potentially produce high seeds as well. Figure 4 shows the highest seed yield on Demas 1 cultivar which was given bokashi banana dose 20 t.ha $^{-1}$ that is equal to 59,03 g.pot ${ }^{-1}$; followed by seed yield of Demas 1 cultivar also on bokashi dosage 40 ; 60 ; and 0 t.ha $^{-1}$ respectively 51.11 ;
47,11; and 38,72 g.pot ${ }^{-1}$. Soybean cultivars that have lower seed yields below the cultivars Demas 1 seeds are Argomulyo, Gepak Ijo and Anjasmoro. The soybean cultivars that have the lowest seed yield is Gema and Gamasugen 1 with the average yield of seeds is only 7.64 and 7.82 g.pot $^{-1}$.

Demas 1 is the soybean cultivar with the highest yield among the cultivars tested. Provision of bokashi increases the yield of the cultivar seed Demas 1 . This cultivar increased the yield of the seeds significantly when given bokashi with a dose of $20 \mathrm{t}^{\mathrm{tha}} \mathrm{a}^{-1}$, but the seed yield decreased when given bokashi with higher doses. Cultivars Argomulyo, Anjasmoro and Slamet, have moderate seed yields, lower than Demas 1 cultivars. This cultivar group also increased the yield of seeds when given 20 t.ha $^{-1}$ bokashi and decreased at higher doses. Gepak Ijo includes cultivars with moderate seed yields, but this cultivar does not increase as a result when dberi bokashi. Other soybean cultivars have low yields and do not increase the yield of seeds if given bokashi with any dose between 20 to 60 t.ha $^{-1}$. From this research it can be seen that high yield soybean cultivars, responsive to bokashi, soybean cultivars with moderate results are responsive but others are unresponsive, while cultivars with low yields are not responsive with bokashi.

\section{Conclusion}

Bokashi made from banana stem has a chemical composition that can be used as a soil conditioner as well as a source of nutrients for to increase the growth and yield of soybean crops in coastal sand area. The growth of leaf area, dry weight of roots and canopy, as well as the yield of seeds of several varieties of soybean varied on bokashi dose given. Demas 1 cultivars include soybean cultivars that respond to banana stem bokashi, the growth and yield of the seeds increases with bokashi up to optimum dose, and does not increase again at higher doses. Other cultivars of soybean cultivars are like Demas 1, but some are unresponsive to bokashi or even depressed growth and yield of seeds when given banana stem bokashi.

\section{Acknowledgment}

The authors would like to thank the Directorate General of Higher Education, the Ministry of Education of Research, Technology and Higher Education of the Republic of Indonesia for the opportunity of scholarship of the domestic graduate program in the country data collection at field level.

\section{References}

1. Bloom AL (1979) Geomorphology: A systematic analysis of late cenozoic landforms. Prentice Hall of India Pvt Ltd New Delhi pp. 253-276.

2. Shiddieq D, Kertonegoro BD, Sudana W, Dariah A (2007) Executive summary of research results of 2007. Partnership of Agricultural Research Cooperation with Universities (KKP3T), Ministry of Agriculture, Jakarta, Indonesia.

3. Sunardi, Sarjono Y (2007) Determination of Macro Elements Content at Samas Beach Area Bantul with Neutron Activation Analysis Method (AAN) Proceeding PPI - PDIPTN 2007 Technology Centre Accelerator and Process Materials - BATAN, Yogyakarta pp. 123-129.

4. Partoyo (2005) Analysis of soil quality index for sand dune agriculture land At Samas Yogyakarta. IImu Pertanian 12: 140-151.

5. Saparso, Harsono S, Tohari (2003) Cabbage plant development in coastal sand land: Plant growth in various combinations of mulch and nitrogen fertilization. Jurnal Agrin 7: 60-73.

6. Howarth RW (2007) Coastal nitrogen pollution: A review of sources and trends a globally and regionally. Harmful Algae 8: 14-20.

7. Evanylo G, Sherony C, Spargo J, Starner D, Brosius M, et al. (2008) Soil and water environmental effects of fertilizer-, manure-, and compost-based fertility practices in an organic vegetable cropping system. Agric Ecosyst Environ 127: $50-58$.

8. Salvagiotti F, Cassman KG, Specht JE, Walters DT, Weiss A et al. (2008) 
Citation: Faozi K, Yudono P, Indradewa D, Ma'as A (2018) Banana Stem Bokashi and its Effect to Increase Soybean Yield (Glycine max L. Merrill) in Coastal Sands Area. Agrotechnology 7:184. doi: 10.4172/2168-9881.1000184

Page 7 of 7

Nitrogen uptake, fixation and response to fertilizer $\mathrm{N}$ in soybeans: A review. Field Crops Res 108: 1-13.

9. Sunarto, Riyanto A, Faozi K (2010) Stability of Genotypes of Large Soybean Seed in Fertile Land and Coastal Sands as well as optimization of planting distance arrangement and manure application. National Strategic Research Grant for 2010 Fiscal Year. Jenderal Soedirman University, Purwokerto.

10. Krisnawati A, Adie MM (2015) Selection of soybean genotypes by seed size and its prospects for industrial raw material in Indonesia. Procedia Food Science 3: 355-363.

11. Saparso, Tohari, Shiddieq D, Setiadi B (2008) Optimizing the productivity of coastal sand land through the cultivation of cabbages under shade and bentonite coating. Jurnal Agrin 12: 100-113.

12. Syukur A, Harsono ES (2008) Influence of manure and NPK fertilize application to some chemical and physics of Samas Coastal Land, Bantul. Jurnal IImu Tanah dan Lingkungan 8: 138-145.

13. Rajiman, Yudono P, Sulistyaningsih E, Hanudin E (2008) The effect of soil conditioners on the nature of soil physics and Red Onion yields on Bugel Beach of Kulon Progo Regency. Jurnal Agrin 12: 67-77.

14. Hall DJM, Bell RW (2015) Biochar and compost increase crop yields but the effect is short Term on Sandplain Soils of Western Australia. Pedosphere 25: 720-728.

15. Pemkab Bantul (2018) Bantul Panen Pisang (Berita).

16. Lim SL, Lee HL, Wu TY (2016) Sustainability of using composting and vermicomposting technologies for organic solid waste biotransformation: Recent overview, greenhouse gases emissions and economic analysis. J Clean Prod 111: 262-278.

17. Elnour M, Elfadil AG, Manal FA, Saeed BAE (2015) Effects of banana compost on growth, development and productivity of sorghum bicolor cultivar (Tabat). JAB 8: 1554-1561.

18. Kusmiadi R, Khodijah NS, Royalaitani (2015) Added banana stem to chicken fur compost with different types of activator. J Agric Environ 8: 19-30.

19. Wulandari AS, Mansur I, Sugiarti H (2011) Effect of addition of Banana stem compost on the growth of Jabon (Anthocephalus cadamba Miq.) seedling growth. J Silvik Tropika 3: 78-81.

20. Mohapatra D, Mishra S, Sutar N (2010) Banana and its by-product utilisation: An overview. J Sci Ind Res India 69: 323-329.

21. Iskak P, Paris J, Retnowati Y (2015) Bokhasi quality test based on banana tree stem (Musa sp.). Department of Biology, Gorontalo State University, Indonesia

22. Kusumawati A (2015) Analysis of the characteristics of compost fertilizer made from banana stems. Proceedings National Seminar of PGRI University Yogyakarta 2015, PGRI University, Yogyakarta, Indonesia, pp: 322-328.

23. Triyanto KBT (2016) Guide to making bokashi fertilizer from rice straw.

24. Mylavarapu R, Zinati G (2009) Improvement of soil properties using compost for optimum parsley production in sandy soils. Sci Hortic 120: 426-430.

25. Gardner FP, Pearce RB, Mitchell RL (1991) Physiology of crop plant. UI Press Translation. Jakarta, Indonesia 428p.

26. Sitompul SM, Guritno B (1995) Analysis of plant growth. Gadjah Mada University Press, Yogyakarta. 411p.

27. Salisbury FB, Ross CW (1992) Plant Physiology, Volume 3 (Indonesian) Translated by Diah R Lukman dan Sumaryono. Bandung, Indonesia. 343p.

28. Nakhro N, Dkhar MS (2010) Impact of organic and Inorganic fertilizers on microbial populations and biomass carbon in paddy field soil. J Agron 9: 102110.

29. Faozi K (2018) Soybean Growth and Yield on Bokashi Banana Fruits in Beach Sand Fields. Doctoral Program in Agricultural Sciences, Universitas Gadjah Mada, Yogyakarta, Indonesia 364p.

30. Whigham DK (1983) Soybean. In symposium on potential productivity of field crops under different environments. Int Rice Res Inst, Los Banos, Philippines. pp: 205-225. 